\title{
Penerapan Model Problem Based Learning (PBL) Untuk Meningkatkan Hasil Belajar Matematika Peserta Didik Kelas VII-A SMP Negeri 40 Pekanbaru
}

\author{
Resti Dwi Junita ${ }^{1}$, Titi Solfitri ${ }^{2}$, Syarifah Nur Siregar ${ }^{3}$ \\ 1,2,3Pendidikan Matematika, Universitas Riau \\ resti.dwijunita@student.unri.ac.id
}

\begin{abstract}
This research aims to improve the learning process and improve students' mathematics learning outcomes through the application of the Problem Based Learning (PBL) model. This research is a classroom action research consisting of two cycles, each cycle consisting of 3 meetings and one daily test. The research instrument used was a learning tool consisting of a syllabus, lesson plans (RPP), student worksheets (LKPD), and data collection instruments, namely observation sheets and mathematics learning outcomes test. Data collection techniques are observation techniques and test techniques. Observation sheets were analyzed descriptively narrative while learning outcomes tests were analyzed statistically descriptive. The research subjects were students of class VII-A SMP Negeri 40 Pekanbaru for the 2019/2020 academic year, which consisted of 39 students. Based on the qualitative data analysis, it was concluded that there was an improvement in the learning process after applying the PBL model, namely that students were actively participating and increasingly independent in the learning process, presenting the results of problem-solving and providing learning conclusions. In quantitative data analysis, the percentage of students who reached the KKM knowledge competency on the raw score was $12.82 \%$, increasing to $46.15 \%$ in the first cycle and increasing to $66.67 \%$ in the second cycle. In skill competency, the percentage of students who reached the KKM in the first cycle was 33.33\%, rising to $56.41 \%$ in the second cycle. Based on the research results, it can be concluded that the application of the Problem Based Learning model can improve the learning process and can improve the mathematics learning outcomes of class VII-A students of SMP Negeri 40 Pekanbaru.
\end{abstract}

Keywords: Learning Outcomes, Action Research, Problem Based Learning

\begin{abstract}
ABSTRAK Penelitian ini bertujuan untuk memperbaiki proses pembelajaran dan meningkatkan hasil belajar matematika peserta didik melalui penerapan model Problem based learning (PBL). Penelitian ini merupakan penelitian tindakan kelas yang terdiri dari dua siklus, setiap siklus terdiri dari 3 pertemuan dan 1 kali ulangan harian. Instrumen penelitian yang digunakan adalah perangkat pembelajaran yang terdiri dari Silabus, Rencana Pelaksanaan Pembelajaran (RPP) dan Lembar Kerja Peserta Didik (LKPD) serta instrumen pengumpul data yaitu lembar pengamatan dan tes hasil belajar matematika. Teknik pengumpulan data adalah teknik pengamatan dan teknik tes. Lembar pengamatan dianalisis secara deskriptif naratif, sedangkan tes hasil belajar dianalisis secara statistik deskriptif. Subjek penelitian adalah peserta didik kelas VII-A SMP Negeri 40 Pekanbaru tahun pelajaran 2019/2020 yang terdiri dari 39 peserta didik. Berdasarkan analisis data kualitatif disimpulkan bahwa terjadi perbaikan proses pembelajaran setelah menerapkan model PBL, yaitu peserta didik terlihat berpartisipasi aktif dan semakin mandiri dalam proses pembelajaran, mempresentasikan hasil penyelesaian masalah dan memberikan kesimpulan pembelajaran. Pada analisis data kuantitatif, persentase jumlah peserta didik yang mencapai KKM kompetensi pengetahuan pada skor dasar yaitu $12,82 \%$ meningkat menjadi $46,15 \%$ pada siklus pertama dan meningkat menjadi $66,67 \%$ pada siklus kedua. Pada kompetensi keterampilan, persentase jumlah peserta didik yang mencapai KKM pada
\end{abstract}


siklus pertama yaitu 33,33\% meningkat menjadi 56,41\% pada siklus kedua. Berdasarkan hasil penelitian dapat disimpulkan bahwa penerapan model Problem Based Learning dapat memperbaiki proses pembelajaran dan dapat meningkatkan hasil belajar matematika peserta didik kelas VII-A SMP Negeri 40 Pekanbaru.

Kata-kata Kunci : Hasil Belajar Matematika, Penelitian Tindakan Kelas, Problem Based Learning

\section{PENDAHULUAN}

Pengembangan Kurikulum 2013 merupakan langkah lanjutan Pengembangan Kurikulum Berbasis Kompetensi (KBK) yang telah dirintis pada tahun 2004 dan KTSP 2006 yang mencakup kompetensi sikap, pengetahuan, dan keterampilan secara terpadu. Implementasi Kurikulum 2013 dalam proses pembelajaran matematika merupakan pelaksanaan program kurikulum ke dalam praktik pembelajaran matematika, sehingga terjadi perubahan dalam diri peserta didik baik pengetahuan, keterampilan maupun sikap.

Adapun tujuan pembelajaran matematika yang tercantum dalam kurikulum 2013 yaitu agar siswa dapat: (1) memahami konsep matematis; (2) menggunakan pola sebagai dugaan dalam penyelesaian masalah dan mampu membuat generalisasi berdasarkan fenomena atau data yang ada; (3) menggunakan penalaran pada sifat, melakukan manipulasi matematika baik dalam penyederhanaan, maupun menganalisa komponen yang ada dalam pemecahan masalah dengan konteks matematika maupun di luar matematika; (4) mengkomunikasikan gagasan, penalaran, serta mampu menyusun bukti matematika dengan menggunakan kalimat lengkap, simbol, tabel, diagram, atau media lain untuk memperjelas keadaan atau masalah; (5) memiliki sikap menghargai kegunaan matematika dalam kehidupan; (6) memiliki sikap dan prilaku yang sesuai dengan nilai-nilai dalam matematika dan pembelajarannya; (7) melakukan kegiatan- kegiatan motorik yang menggunakan pengetahuan matematika; dan (8) menggunakan alat peraga sederhana atau hasil teknologi untuk melakukan kegiatan-kegiatan matematika (Permendikbud Nomor 58, 2014).

Ketercapaian tujuan pembelajaran yang dimiliki peserta didik dapat dilihat dari tingkat keberhasilan dan ketuntasan hasil belajar matematika yang diperoleh peserta didik yang didasarkan pada Kriteria Ketuntasan Minimal (KKM). KKM adalah kriteria ketuntasan belajar yang ditentukan oleh satuan pendidikan yang mengacu pada standar kompetensi kelulusan dengan mempertimbangkan karakteristik pesertadidik, karakteristik mata pelajaran dan kondisi satuan pendidikan (Permendikbud Nomor 23, 2016).

Berdasarkan informasi yang peneliti peroleh dari guru matematika kelas VII-A SMP Negeri 40 Pekanbaru, masih banyak peserta didik yang belum mencapai KKM yang ditetapkan sekolah yaitu 65. Jumlah peseta didik kelas VII-A SMP Negeri 40 Pekanbaru tahun pelajaran 2019/2020 semester ganjil, yang mencapai KKM pada ulangan harian (UH) matematika pada materi pokok bilangan adalah 5 dari 39 peserta didik, $(12,82 \%)$. Hal ini menunjukkan bahwa masih banyak peserta didik yang belum 
memahami pelajaran matematika sehingga menyebabkan hasil belajar matematika yang rendah.

Wawancara yang dilakukan peneliti dengan guru matematika dan observasi di kelas VII-A SMP Negeri 40 Pekanbaru, menunjukkan terdapat beberapa permasalahan dalam proses pembelajaran. Permasalahan tersebut antara lain, proses pembelajaran yang diterapkan masih konvensional yaitu pembelajaran masih banyak didominasi oleh guru sehingga peserta didik cenderung pasif dalam membangun pengetahuannya sendiri dan belum menunjukkan adanya kemauan dan motivasi yang baik, peserta didik kurang berpartisipasi aktif dalam proses pembelajaran dan hanya didominasi oleh peserta didik yang berkemampuan akademis tinggi, peserta didik mengalami kesulitan dalam mengerjakan soal yang berbentuk masalah. Sejalan dengan kondisi permasalahan sebelumnya, perlu diterapkan suatu model pembelajaran yang berpusat pada peserta didik yang dapat mengaktifkan peserta didik dalam memahami permasalahan dalam kehidupan nyata, merangsang berfikir kritis dan meningkatkan keaktifan peserta didik. Salah satu model pembelajaran yang dapat mengatasi permasalahan tersebut adalah model Problem Based Learning (PBL).

Arend (dalam Trianto, 2014)menyatakan bahwa PBL merupakan suatu pendekatan pembelajaran yang berfokus pada peserta didik dengan menggunakan masalah dalam dunia nyata yang bertujuan untuk menyusun pengetahuan peserta didik, melatih kemandirian dan rasa percaya diri dan mengembangkan keterampilan berpikir peserta didik dalam pemecahan masalah. Hamalik (2014) berpendapat bahwa belajar merupakan perubahan perbuatan melalui aktivitas, praktik dan pengalaman. Melalui PBL yang pengajarannya berawal dari persoalan dalam dunia nyata, diharapkan pembelajaran matematika dapat menjadi bermakna bagi peserta didik, dengan demikian dapat menarik minat peserta didik terhadap pelajaran matematika, serta dapat meningkatkan hasil belajar peserta didik. Menurut (Faturrohman, 2016) tahapan-tahapan PBL yang dilaksanakan secara sistematis berpotensi dapat mengembangkan kemampuan peserta didik dalam menyelesaikan masalah dan sekaligus dapat menguasai pengetahuan yang sesuai dengan kompetensi dasar tertentu

Berdasarkan masalah tersebut, peneliti melakukan penelitian dengan menerapkan model PBL untuk meningkatkan hasil belajar siswa kelas VII-A SMP Negeri 40 Pekanbaru pada tahun ajaran 2019/ 2020 materi himpunan yaitu pada kompetensi dasar: 3.4 Menjelaskan himpunan, himpunan bagian, himpunan semesta, himpunan kosong, komplemen himpunan, dan melakukan operasi biner pada himpunan menggunakan masalah kontekstual; dan 4.4 Menyelesaikan masalah kontekstual yang berkaitan dengan himpunan, himpunan bagian, himpunan semesta, himpunan kosong, komplemen himpunan dan operasi biner pada himpunan. Pemilihan materi pokok himpunan dikarenakan banyak permasalahan sehari-hari yang beragam di kehidupan peserta didik yang berhubungan dengan himpunan. Oleh karena itu, peserta didik perlu berlatih meningkatkan kemampuan memecahkan masalah yang berhubungan dengan himpunan. 


\section{METODE PENELITIAN}

Jenis penelitian yang dilakukan adalah penelitian tindakan kelas pola kolaboratif. Kunandar (2011) menyatakan bahwa pengamatan dalam PTK adalah kegiatan mengumpulkan data berupa proses perubahan kinerja. Peneliti dan guru bekerja sama dalam proses pelaksanaan tindakan. Pelaksanaan tindakan dilakukan oleh peneliti dan sebagai pengamatnya adalah guru matematika kelas VII-A SMP Negeri 40 Pekanbaru. Penelitian ini terdiri dari dua siklus, masing-masing siklus terdiri dari 3 kali pertemuan satu kali ulangan harian. Sehubungan dengan pelaksanaan tindakan untuk setiap siklus, peneliti menggunakan empat tahap, yaitu perencanaan, tindakan, pengamatan dan refleksi (Arikunto, dkk, 2017).

Subjek penelitian ini adalah siswa kelas VII-A SMP Negeri 40 Pekanbaru dengan jumlah 39 orang peserta didik, 20 orang peserta didik laki-laki dan 19 orang peserta didik perempuan dengan tingkat kemampuan yang heterogen. Perangkat pembelajaran yang digunakan adalah Silabus, Rencana Pelaksanaan Pembelajaran (RPP) dan Lembar Kerja Peserta Didik (LKPD). Instrumen pengumpulan data terdiri dari lembar pengamatan dan lembar tes hasil belajar matematika. Lembar pengamatan terdiri dari lembar pengamatan aktivitas guru dan lembar pengamatan aktivitas peserta didik yang digunakan untuk memperoleh data aktivitas guru dan peserta didik selama proses pembelajaran. Perangkat tes hasil belajar terdiri dari kisi-kisi penulisan soal, naskah soal ulangan harian dan alternatif jawaban serta pedoman penskoran ulangan harian.

Teknik pengumpulan data pada penelitian ini adalah teknik pengamatan dan teknik hasil belajar. Menurut Muslich (2010) tahapan dalam analisis data kualitatif terdiri dari tiga tahap, yaitu reduksi data, paparan data dan penarikan kesimpulan. Pengumpulan data aktivitas guru dan peserta didik menggunakan teknik pengamatan. Pengumpulan data hasil belajar peserta didik dikumpulkan melalui tes hasil belajar. Data tentang aktivitas guru dan peserta didik dianalisis dengan teknik analisis deskriptif naratif. Data yang diperoleh dari tes hasil belajar dianalisis dengan teknik analisis statistik deskriptif, yaitu terdiri dari analisis ketercapaian KKM dan analisis data distribusi frekuensi.

Pada penelitian ini analisis ketercapaian KKM dilakukan dengan membandingkan persentase jumlah peserta didik yang mencapai KKM pada skor dasar dan persentase jumlah peserta didik yang mencapai KKM pada tes hasil belajar dengan menerapkan model PBL yaitu pada UH-I dan UH-II. Peserta didik dikatakan tuntas apabila mencapai nilai minimal 65. Persentase jumlah peserta didik yang mencapai KKM dihitung dengan menggunakan rumus berikut.

$$
P=\frac{J P K}{J P S} X 100 \%
$$

Keterangan:

P : Persentase jumlah peserta didik yang mencapai KKM

JPK : Jumlah peserta didik mencapai KKM

JPS : Jumlah peserta didik seluruhnya 
Tindakan yang dilakukan berhasil jika persentase jumlah peserta didik yang mencapai KKM meningkat dari sebelum dilakukan tindakan dibandingkan setelah dilakukan tindakan atau jumlah peserta didik yang mencapai KKM semakin banyak dari sebelum dilakukan tindakan dengan setelah dilakukan tindakan.

Pada penelitian ini data hasil belajar peserta didik pada skor dasar, skor UH-I dan skor UH-II disajikan ke dalam tabel distribusi frekuensi. Pembuatan tabel distribusi frekuensi pada penelitian ini mengacu kepada (Tim Direktorat Pembinaan SMP, 2017). Panjang interval pada pembuatan tabel distribusi frekuensi ditentukan dengan rumus:

$$
P=\frac{(N M-N K)}{3}
$$

Keterangan:

$P \quad$ : Panjang interval

NM : Nilai maksimum

NK : Nilai KKM

Tabel 1. Interval Nilai untuk KKM 65

\begin{tabular}{cc}
\hline Interval Nilai & Kriteria \\
\hline $89-100$ & Sangat Baik \\
\hline $77-88$ & Baik \\
\hline $65-76$ & Cukup \\
\hline$<65$ & Kurang \\
\hline
\end{tabular}

Sumber : Tim Direktorat Pembinaan SMP

Hasil belajar dikatakan meningkat jika pada tabel distribusi terlihat bahwa frekuensi peserta didik yang memperoleh nilai pada interval yang berada di bawah KKM berkurang dari skor dasar ke UH-I dan dari skor UH-I ke skor UH-Il atau frekuensi peserta didik yang memperoleh nilai pada interval yang berada di atas KKM meningkat dari skor dasar ke skor UH-I dan dari skor UH-I ke skor UH-II.

Kriteria keberhasilan tindakan pada penelitian ini adalah terjadinya perbaikan proses pembelajaran dan terjadinya peningkatan hasil belajar peserta didik. Terjadinya perbaikan proses pembelajaran jika proses pembelajaran yang dilakukan semakin baik dari siklus I ke siklus II. Selain itu terjadi kesesuaian antara langkah-langkah penerapan model PBL yang direncanakan dengan pelaksanaan tindakan pada proses pembelajaran yang dapat dilihat dari lembar pengamatan setiap pertemuan. Terjadinya peningkatan hasil belajar dapat dilihat berdasarkan analisis data distribusi frekuensi dan analisis ketercapaian KKM.

\section{HASIL DAN PEMBAHASAN}

Penerapan Model PBL yang direncanakan pada pelaksanaan tindakan dalam proses pembelajaran secara garis besar terlaksana sesuai dengan RPP. Berdasarkan analisis data tentang aktivitas guru dan peserta didik pada penerapan PBL sudah semakin sesuai dengan perencanaan pembelajaran dan proses pembelajaran juga semakin membaik. Sebagian besar peserta didik semakin aktif dalam setiap langkah menyelesaikan masalah. Penerapan model PBL yang dilakukan peneliti memberikan 
dampak positif pada pelaksanaan proses pembelajaran yaitu peserta didik menjadi lebih aktif dalam kegiatan pembelajaran sehingga pembelajaran tidak berpusat pada guru. Peserta didik juga terlatih untuk membangun pengetahuannya sendiri sehingga pembelajaran menjadi lebih bermakna dan lebih melekat diingatan peserta didik. Hal ini memberikan pengaruh terhadap hasil belajar peserta didik.

Ditinjau dari hasil belajar matematika, peningkatan hasil belajar dilihat dari analisis ketercapaian KKM pada kompetensi pengetahuan dan keterampilan dan analisis distribusi frekuensi. Analisis ketercapaian KKM Pengetahuan pada KD 3.4 Menjelaskan himpunan, himpunan bagian, himpunan semesta, himpunan kosong, komplemen himpunan, dan melakukan operasi biner pada himpunan menggunakan masalah kontekstual disajikan dalam Tabel 2 berikut.

Tabel 2. Persentase Ketercapaian KKM Hasil Belajar Pengetahuan Peserta Didik

\begin{tabular}{lccc}
\hline & $\begin{array}{c}\text { Sebelum } \\
\text { Tindakan }\end{array}$ & UH-I & UH-II \\
\hline $\begin{array}{l}\text { Jumlah peserta didik yang } \\
\text { mencapai KKM }\end{array}$ & 5 & 18 & 24 \\
\hline $\begin{array}{l}\text { Persentase peserta didik yang } \\
\text { mencapai KKM (\%) }\end{array}$ & 12,82 & 46,15 & 61,54 \\
\hline Sumber: Olah Data Peneliti & & &
\end{tabular}

Berdasarkan Tabel 2, dapat dikatakan bahwa terjadi peningkatan jumlah peserta didik yang mencapai KKM dari skor dasar (sebelum tindakan) ke UH-I (sesudah tindakan), serta ditandai dengan meningkatnya persentase peserta didik yang mencapai KKM sebesar 33,33\% dari skor dasar ke UH-I dan dari UH-I ke UH-II meningkat sebesar 15,39\%. Sehingga dapat dikatakan bahwa hasil belajar matematika peserta didik pada kompetensi pengetahuan meningkat.

Analisis ketercapaian KKM Kompetensi Keterampilan KD 4.4 Menyelesaikan masalah kontekstual yang berkaitan dengan himpunan, himpunan bagian, himpunan semesta, himpunan kosong, komplemen himpunan dan operasi biner pada himpunan disajikan dalam Tabel 3 berikut.

Tabel 3. Persentase Ketercapaian KKM Hasil Belajar Keterampilan Peserta Didik

\begin{tabular}{lcc}
\hline & UH-I & UH-II \\
\hline $\begin{array}{l}\text { Jumlah peserta didik yang } \\
\text { mencapai KKM }\end{array}$ & 10 & 19 \\
\hline $\begin{array}{l}\text { Persentase peserta didik yang } \\
\text { mencapai KKM (\%) }\end{array}$ & 25,64 & 48,72 \\
\hline Sumber: Olah Data Peneliti & &
\end{tabular}

Berdasarkan Tabel 3, dapat dikatakan bahwa Jumlah peserta didik yang mencapai KKM pada kompetensi keterampilan dari UH-I ke UH-II meningkat. Hal ini dapat dikatakan juga meningkatnya persentase peserta didik yang mencapai KKM dari 
UH-I ke UH-II meningkat sebesar 23,08\%. Sehingga dapat dikatakan bahwa hasil belajar matematika peserta didik pada kompetensi keterampilan meningkat. Berdasarkan analisis ketercapaian KKM kompetensi pengetahuan dan keterampilan, persentase peserta didik yang mencapai KKM pada Tabel 2 dan 3 dapat disimpulkan bahwa jumlah peserta didik kelas VII-A SMP Negeri 40 Pekanbaru yang mencapai KKM kompetensi pengetahuan dan keterampilan dari siklus I ke siklus II mengalami peningkatan.

Analisis data hasil belajar matematika peserta didik dapat dilihat dari analisis data distribusi frekuensi, untuk melihat penyebaran frekuensi nilai peserta didik. Dengan demikian dapat diketahui peningkatan hasil belajar matematika peserta didik sebelum dilakukan tindakan ke setelah dilakukan tindakan (UH-I dan UH-II). Hasil belajar matematika peserta didik ini merupakan hasil belajar pada kompetensi pengetahuan dan keterampilan. Pada Tabel distribusi frekuensi dapat dilihat peningkatan atau penurunan hasil belajar matematika peserta didik dari sebelum tindakan ke setelah dilakukan tindakan, serta juga dapat melihat frekuensi peserta didik yang belum mencapai KKM dari sebelum dilakukan tindakan ke setelah dilakukan tindakan (UH-I dan UH-II). Distribusi frekuensi hasil belajar matematika peserta didik kompetensi pengetahuan dapat dilihat pada Tabel 4.

Tabel 4. Distribusi Frekuensi Hasil Belajar Matematika Peserta Didik

Pada Aspek Kompetensi Pengetahuan

\begin{tabular}{ccccc}
\hline \multirow{2}{*}{ Interval Nilai } & \multicolumn{3}{c}{ Frekuensi Peserta Didik } & \multirow{2}{*}{ Kategori Nilai } \\
& Skor Dasar & UH-I & UH-II & \\
\hline $89-100$ & 1 & 3 & 4 & Sangat Baik \\
$77-88$ & 0 & 5 & 12 & Baik \\
$65-76$ & 4 & 10 & 10 & Cukup \\
\hline $53-64$ & 7 & 5 & 5 & \\
$41-52$ & 5 & 8 & 4 & Kurang \\
$29-40$ & 11 & 5 & 4 & \\
$17-28$ & 7 & 2 & 0 & \\
$5-16$ & 4 & 1 & 0 & \\
\hline
\end{tabular}

Sumber: Olah Data Peneliti

Berdasarkan Tabel 4, dapat diketahui bahwa jumlah peserta didik di kategori nilai kurang dengan interval 5-16, 17-28, dan 29-40 yaitu 22 peserta didik pada skor dasar, pada UH I terjadi penurunan menjadi 8 peserta didik dan pada UH II terjadi penurunan jumlah peserta didik menjadi 4 peserta didik. Pada kategori nilai kurang yaitu interval 41-52 dan 53-64 sebanyak 12 peserta didik pada skor dasar, pada UH I terjadi kenaikan jumlah peserta didik menjadi 13 peserta didik dan pada UH || terjadi penurunan menjadi 9 peserta didik. Pada kategori nilai cukup yaitu interval 65-76 yaitu 4 peserta didik terjadi peningkatan dari skor dasar dan UH I menjadi 10 peserta didik, pada UH I I tidak terjadi peningkatan ataupun penurunan jumlah peserta didik. Pada kategori nilai baik yaitu interval 77-88 terjadi peningkatan pada UH I yaitu 5 peserta didik dan UH II terjadi kenaikan jumlah peserta didik 12 peserta didik. Pada kategori nilai sangat baik yaitu interval 89-100 jumlah peserta didik pada skor dasar 
yaitu 1 peserta didik, pada UH I terjadi peningkatan menjadi 3 peserta didik dan pada UH II menjadi 4 peserta didik. Selanjutnya distribusi frekuensi dari hasil belajar matematika peserta didik pada kompetensi keterampilan pada UH I dan UH II disajikan pada tabel berikut ini.

Tabel 5. Distribusi Frekuensi Hasil Belajar Matematika Peserta Didik Pada Aspek Kompetensi Keterampilan

\begin{tabular}{cccc}
\hline Interval Nilai & \multicolumn{2}{c}{ Frekuensi Peserta Didik } & Kategori Nilai \\
& UH-I & UH-II & \\
\hline $89-100$ & 3 & 7 & Sangat Baik \\
$77-88$ & 6 & 2 & Baik \\
$65-76$ & 4 & 13 & Cukup \\
\hline $53-64$ & 5 & 2 & \\
$41-52$ & 10 & 8 & Kurang \\
$29-40$ & 1 & 5 & \\
$17-28$ & 7 & 2 & \\
$5-16$ & 3 & 0 & \\
\hline
\end{tabular}

Sumber : Olah Data Peneliti

Berdasarkan Tabel 5, dapat diketahui bahwa jumlah peserta didik di kategori nilai kurang dengan interval 5-16, 17-28, dan 29-40 yaitu 11 peserta didik pada UH I dan pada UH II terjadi penurunan jumlah peserta didik menjadi 7 peserta didik. Pada kategori nilai kurang yaitu interval 41-52 dan 53-64 sebanyak 15 peserta didik pada UH I dan pada UH II terjadi penurunan menjadi 10 peserta didik. Pada kategori nilai cukup yaitu interval 65-76 jumlah peserta didik pada UH I yaitu 4 peserta didik dan pada UH II terjadi peningkatan menjadi 13 peserta didik. Pada kategori nilai baik yaitu interval 77-88 jumlah peserta didik pada UH I yaitu 6 peserta didik, pada UH II mengalami penurunan menjadi 2 peserta didik dikarenakan beberapa nilai peserta didik pada interval tersebut mengalami kenaikan pada interval 89-100. Pada kategori nilai sangat baik yaitu interval 89-100 jumlah peserta didik pada UH I yaitu 3 peserta didik dan pada UH II mengalami kenaikan menjadi 7 peserta didik.

Hal tersebut menunjukkan bahwa setelah pelaksanaan tindakan terjadi peningkatan hasil belajar matematika peserta didik pada kompetensi keterampilan yang ditandai dengan perubahan frekuensi peserta didik ke interval cukup, baik dan sangat baik (ke arah yang lebih baik) meningkat, dari frekuensi peserta didik yang kategori kurang berkurang dari sebelum dilakukan tindakan ke setelah dilakukan tindakan. Berdasarkan Tabel 4 dan Tabel 5, dapat dilihat bahwa setelah pelaksanaan tindakan terjadi peningkatan hasil belajar matematika peserta didik pada kompetensi pengetahuan dan keterampilan.

\section{Pembahasan Hasil Penelitian}

Hasil analisis data aktivitas guru dan peserta didik pada penerapan PBL sudah terlaksana sesuai dengan perencanaan pembelajaran dan proses pembelajaran semakin membaik. Selama proses pembelajaran di kelas VII-A SMP Negeri 40 Pekanbaru tahun ajaran 2019/2020, terlihat bahwa peserta didik berperan aktif 
dalam memecahkan masalah yang diberikan. Penerapan model PBL yang peneliti lakukan memiliki dampak positif terhadap proses pembelajaran dimana peserta didik menjadi lebih aktif dalam pembelajaran sehingga poembelajaran tidak berpusat pada guru.

Berdasarkan analisis ketercapaian KKM pengetahuan dan keterampilan, terjadi peningkatan jumlah peserta didik yang mencapai KKM dari skor dasar ke siklus I dan siklus II. Sejalan dengan pendapat yang dikemukakan oleh Sanjaya (2016) yang mengatakan bahwa PTK dikatakan berhasil mana kala masalah yang dikaji semakin mengerucut atau tindakan setiap siklus masalah semakin terpecahkan sedangkan dilihat dari hasil belajar matematika yang diperoleh semakin besar, hasil belajar matematika dari siklus ke siklus semakin meningkat. Secara umum, peserta didik kurang teliti dalam menyelesaikan soal. Sedangkan berdasarkan uraian tentang analisis aktivitas guru dan peserta didik, serta analisis peningkatan hasil belajar peserta didik, dapat dikatakan bahwa terjadi proses perbaikan dalam pelaksanaan pembelajaran juga meningkatnya nilai peserta didik yang mencapai KKM sehingga hasil analisis penelitian mendukung hipotesis tindakan yang diajukan yaitu, jika model PBL dapat memperbaiki proses pembelajaran dan dapat meningkatkan hasil belajar peserta didik kelas VII-A SMP Negeri 40 Pekanbaru tahun ajaran 2019/ 2020 pada materi himpunan.

Selama penelitian berlangsung terdapat beberapa kendala yang tidak lepas dari kekurangan peneliti dalam proses pembelajaran, di antaranya pada siklus I proses pembelajaran belum terlaksana sebagimana yang telah direncanakan dan peserta didik belum terbiasa pada langkah-langkah PBL. Kekurangan pada siklus I menjadi bahan perbaikan bagi peneliti ada siklus II, sehingga pada siklus II peserta didik lebih aktif dalam proses pembelajaran dan tahapan model PBL dapat terlaksana dengan lebih baik setiap pertemuan.

\section{KESIMPULAN DAN SARAN}

Berdasarkan analisis dan pembahasan, dapat disimpulkan bahwa penerapan model Problem Based Learning dapat memperbaiki proses pembelajaran dan meningkatkan hasil belajar matematika peserta didik kelas VII-A SMP Negeri 40 Pekanbaru ganjil tahun pelajaran 2019/2020 pada materi pokok himpunan. Melalui pembahasan dan simpulan, peneliti mengemukakan rekomendasi yang berhubungan dengan penerapan Problem Based Learning dalam pembelajaran matematika yaitu:

1. Pembelajaran dengan model PBL dapat dijadikan salah satu alternatif model pembelajaran yang dapat diterapkan untuk memperbaiki proses pembelajaran dan meningkatkan hasil belajar matematika peserta didik.

2. Pembelajaran dengan model PBL menjadikan peserta didik berpartisipasi aktif dalam kegiatan diskusi kelompok untuk menyelesaikan masalah sehingga pembelajaran berpusat pada peserta didik.

3. Model PBL adalah pembelajaran yang diawali dengan menyajikan permasalahan kontekstual sehingga dapat menarik minat peserta didik dalam 
menyelesaikan dan dapat meningkatkan hasil belajar, untuk itu bagi guru atau peneliti yang ingin menerapkan model PBL sebaiknya menegaskan peserta didik untuk berdiskusi dengan teman sekelompoknya terlebih dahulu sebelum bertanya kepada guru.

\section{DAFTAR PUSTAKA}

Faturrohman, M. (2016). Model-model Pembelajaran Inovatif: Alternatif Desain Pembelajaran yang Menyenangkan. Ar-Ruzz Media.

Kunandar. (2011). Langkah Mudah Penelitian Tindakan Kelas sebagai Pengembangan Profesi Guru. Rajawali Press.

Muslich, M. (2010). Melaksanakan PTK itu Mudah.

Oemar Hamalik. (2014). Psikologi Belajar dan Mengajar. Sinar Baru Algensindo.

Permendikbud Nomor 23. (2016). Standar Penilaian Pendidikan. https://doi.org/10.31227/osf.io/munp2

Permendikbud Nomor 58. (2014). Peraturan Mendikbud Nomor 58 tahun 2014 tentang Kurikulum 2013 Sekolah Menengah Pertama (SMP) / Madrasah Tsanawiyah (MTs). 20, 1-109.

Suharsimi Arikunto, Suhardjono, dan S. (2017). Penelitian Tindakan Kelas. Bumi Aksara.

Tim Direktorat Pembinaan SMP. (2017). Panduan: Penilaian oleh Pendidik dan Satuan Pendidikan Sekolah Menengah Pertama. 188.

Trianto. (2014). Mendesain Model Pembelajaran Inovatif, Progresif dan Kontekstual: Konsep, Landasan, dan Impelementasinya pada Kurikulum 2013 (Kurikulum Tematik Integratif/KTI). Kencana Prenadamedia Group.

Wina Sanjaya. (2016). Strategi Pembelajaran Berorientasi Standar Proses Pendidikan. Prenadamedia Group. 